\title{
Morfometri Portunus pelagicus Linnaeus, 1758 (Malacostraca : Portunidae) Pada Fase Bulan Yang Berbeda Di Perairan Betahwalang, Demak
}

\author{
Errizal Machmud Putra*, Rini Pramesti, Gunawan Widi Santosa \\ Departemen IImu Kelautan, Fakultas Perikanan dan IImu Kelautan, Universitas Diponegoro \\ JI. Prof. H. Soedarto S.H, Tembalang,Semarang, Jawa Tengah 50275 Indonesia \\ ${ }^{*}$ Corresponding author, e-mail: putraemp@gmail.com
}

\begin{abstract}
ABSTRAK : Rajungan (Portunus pelagicus) merupakan komoditas unggulan Indonesia. Perairan Betahwalang, Kabupaten Demak memiliki sumberdaya rajungan yang potensial dengan tingkat eksploitasi yang tinggi. Rajungan ini ditangkap setiap hari tanpa memperhatikan faktor alam berupa fase bulan yang menyebabkan menurunnya populasi. Informasi penangkapan berdasarkan fase bulan diperlukan agar populasi rajungan dapat terjaga. Tujuan Penelitian ini adalah mengkaji jumlah dan sebaran morfometri rajungan yang tertangkap pada fase bulan purnama dan bulan baru di perairan Betahwalang. Penelitian ini dilakukan dari November 2017 sampai Februari 2018 di perairan Betahwalang. Metode penelitian yang digunakan yaitu metode deskriptif. Penentuan lokasi penelitian berdasarkan area penangkapan rajungan di perairan Betahwalang. Pengambilan data dilakukan 8 kali dari tanggal 5 November 2017 sampai 18 Februari 2018. Pengambilan data berupa jumlah, lebar karapas, berat, jenis kelamin rajungan, dan parameter lingkungan. Hasil penelitian menunjukkan total rajungan tertangkap yaitu 448 ekor, 296 ekor pada Bulan Purnama dan 152 ekor pada Bulan Baru. Morfometri rajungan ukuran $\leq 10 \mathrm{~cm}$ pada Bulan Purnama 190 ekor lebih banyak dari Bulan Baru 90 ekor. Rajungan ukuran $>10 \mathrm{~cm}$ pada Bulan Baru 106 ekor lebih banyak dari Bulan Baru 62 ekor.
\end{abstract}

Kata kunci : Jumlah, Morfometri, Rajungan (Portunus pelagicus), Fase Bulan.

\section{The Morphometry of Portunus pelagicus Linnaeus, 1758 (Malacostraca: Portunidae) at Different Moon Phases in Betahwalang Waters, Demak}

ABSTRACT : Blue Swimming Crab (Portunus pelagicus) is Indonesia's flagship commodity. The waters of Betahwalang, Demak Regancy have potential Blue Swimming Crab resources with high levels of exploitation. The crabs are catched every day regardless of natural factors, such as the moon phase that causes the population to decline. Blue Swimming Crab catch's information based on the moon phase is required for the population to sustaine. The purpose of this research is to study the amount and distribution of Blue Swimming Crab morphometry catched on the full and new moon phase in Betahwalang waters. The study was conducted from November 2017 till February 2018 in the waters of Betahwalang. The research method used was descriptive method. Determination of research location based on Blue Swimming Crab catching area in Betahwalang waters. The data were collected 8 times from November 5, 2017 till February 18, 2018. Data were collected in number, width of carapace, weight, sex, and environmental parameters. The results showed total of catched crabs, were 296 crabs on Full Moon, and 152 crabs on New Moon. Blue Swimming Crab morphometry size $\leq 10 \mathrm{~cm}$ on Full Moon was 190 crabs more than New Moon was 90 crabs. Then, in Size> $10 \mathrm{~cm}$ on New Moon was 106 crabs more than New Moon was 62 crabs.

Keyword: Amount, Morphometry, Blue Swimming Crab (Portunus pelagicus), Moon Phase.

\section{PENDAHULUAN}

Indonesia merupakan negara yang kaya sumber daya hayati, salah satunya yaitu rajungan (Portunus pelagicus). Rajungan adalah kelompok kepiting dari famili portunidae yang hidup di laut. Hewan ini mempunyai kandungan protein yang tinggi sehingga menjadi komoditas unggulan dan ekspornya ke berbagai negara seperti Jepang, Uni Eropa dan Amerika Serikat (Hastuti, 2012). 
Provinsi Jawa Tengah merupakan penghasil rajungan, khususnya Kabupaten Demak. Tahun 2015 produksi rajungan daerah ini 720 ton, tangkapan perhari mencapai 2 ton. Hasil tangkapan terbanyak berasal dari Desa Betahwalang, Kecamatan Bonang, Desa Timbulsloko dan Bedono, Kecamatan Sayung (Ningrum, 2015).

Perairan Betahwalang memiliki sumber daya rajungan yang potensial, namun belum adanya pengaturan zonasi dan waktu penangkapan dapat berakibat menurunnya produktivitas. Produksi yang tinggi disebabkan penangkapan dilakukan setiap hari. Penggunaan alat tangkap bubu yang ramah lingkungan diduga dapat memperoleh rajungan kecil $(\leq 10 \mathrm{~cm})$ dan betina bertelur. Hal ini mengurangi kesempatan hidup rajungan sebelum fase dewasa untuk berkembangbiak.

Hasil tangkapan rajungan diduga berbeda setiap hari yang dipengaruhi kelangsungan hidup, kebiasaan makan, dan reproduksi. Tingkah laku hewan ini diduga dipengaruhi fase bulan. Kurangnya informasi mengenai penangkapan menyebabkan tingginya resiko eksploitasi yang tak terkendali. Hal tersebut mendasari diperlukannya informasi penangkapan rajungan pada fase bulan yang berbeda, sehingga diharapkan menjadi pertimbangan dalam pengelolaan rajungan berkelanjutan di perairan Betahwalang, Kabupaten Demak.

\section{MATERI DAN METODE}

Materi yang digunakan adalah rajungan (Portunus pelagicus) yang ditangkap menggunakan bubu. Penangkapan dilakukan 24 jam dari pagi hingga pagi lagi dengan umpan ikan kecil (bangi). Pengamatan yang dilakukan yaitu jumlah tangkapan rajungan dan morfometri (panjang, lebar dan jenis kelamin) pada fase bulan Purnama dan bulan Baru (November 2017 - Februari 2018). Parameter lingkungan yang diukur yaitu suhu, salinitas, $\mathrm{pH}$, dan kedalaman. Data ini diambil pukul 09.00 WIB dan dilakukan 3 kali pengulangan di perairan Betahwalang, Kabupaten Demak.

Metode penelitian menggunakan metode deskriptif yaitu penelitian yang yang ditujukan untuk mendeskripsikan fenomena-fenomena yang ada (Sukmadinata, 2006). Analisis data menggunakan regresi lebar karapas dengan berat rajungan untuk mengetahui pola pertumbuhan rajungan (Effendie, 2002). Pola pertumbuhan dapat dilihat dari nilai b yang didapat, Jika $b=3$ maka disebut pola pertumbuhan isometric; Jika $b>3$ maka disebut pola pertumbuhan allometrik positif; Jika $b<3$ maka disebut pola pertumbuhan allometrik negatif

Data juga diuji menggunakan Independent Sample $T$ Test untuk mengetahui hubungan jumlah rajungan yang tertangkap dengan fase bulan. Hipotesis yang digunakan yaitu, $\mathrm{HO}$ : tidak ada hubungan antara jumlah rajungan dengan fase bulan; $\mathrm{H} 1$ : ada hubungan antara jumlah rajungan dengan fase bulan. Dasar pengambilan keputusan, Jika nilai signifikansi atau sig. (2tailed) $>0,05$, maka $\mathrm{H} 0$ diterima dan $\mathrm{H} 1$ ditolak; Jika nilai signifikansi atau sig. (2-tailed) $<0,05$, maka $\mathrm{HO}$ ditolak dan $\mathrm{H} 1$ diterima.

\section{HASIL DAN PEMBAHASAN}

Hasil tangkapan rajungan selama 4 bulan (November 2017 - Februari 2018) pada fase bulan Purnama dan bulan Baru yaitu 448 ekor (Tabel 1). Jumlah pada Purnama 296 ekor lebih banyak dari bulan Baru 152 ekor. Hal ini diduga saat bulan Purnama rajungan mudah ditangkap karena aktivitas rajungan meningkat. Menurut Wiyono \& Ikhsan (2015) aktivitas migrasi dan makan rajungan pada saat bulan Purnama meningkat. Jumlah betina pada Purnama 1 dan 4 lebih sedikit daripada jantan sedangkan pada Purnama 2 dan 3 Betina lebih mendominasi. Hal ini diduga fase bulan tidak berpengaruh pada jenis kelamin rajungan yang tertangkap, diperkuat dengan hasil pada bulan Baru jumlah betina pada bulan Baru 1 dan 2 lebih sedikit sedangkan pada 3 dan 4 lebih banyak.

Hubungan jumlah rajungan dengan fase bulan diuji dengan Independent Sample T Test. Nilai Sig. (2-tailed) < 0,05 maka H0 ditolak dan $\mathrm{H} 1$ diterima, ada hubungan (tabel 2). Jumlah rajungan yang tertangkap memiliki hubungan dengan fase bulan. Rajungan yang tertangkap pada fase bulan Purnama lebih banyak dari fase bulan Baru. Hal ini diduga aktivitas rajungan pada fase bulan Purnama meningkat sehingga mudah tertangkap. Menurut Susilo (1993), cahaya bulan pada fase bulan Purnama mengakibatkan aktivitas rajungan meningkat. Jumlah jantan yang tertangkap pada fase bulan Purnama lebih sedikit dari fase bulan Baru. hal tersebut diduga pada kelamin 
jantan penyebarannya pada perairan yang lebih dangkal dengan salinitas yang lebih rendah. Jumlah betina yang tertangkap pada fase bulan Purnama lebih banyak dari fase bulan Baru. Hal ini diduga pengambilan sampel pada kedalaman lebih dari 20 meter. Menurut Adam et al. (2006), betina menyukai perairan dengan salinitas tinggi terutama untuk melakukan pemijahan.

Tabel 1. Jumlah Rajungan yang Tertangkap pada Fase Bulan Purnama dan Bulan Baru di Perairan Betahwalang

\begin{tabular}{ccccccc}
\hline Fase Bulan & Jenis Kelamin & 1 (Nov) & 2 (Des) & 3 (Jan) & 4 (Feb) & Total \\
\hline \multirow{3}{*}{ Purnama } & Jantan & 49 & 32 & 20 & 43 & 144 \\
& Betina & 47 & 38 & 29 & 38 & 152 \\
& Jumlah & $\mathbf{9 6}$ & $\mathbf{7 0}$ & $\mathbf{4 9}$ & $\mathbf{8 1}$ & $\mathbf{2 9 6}$ \\
& Jantan & 26 & 14 & 21 & 16 & 77 \\
\multirow{3}{*}{ Baru } & Betina & 18 & 12 & 24 & 21 & 75 \\
& Jumlah & $\mathbf{4 4}$ & $\mathbf{2 6}$ & $\mathbf{4 5}$ & $\mathbf{3 7}$ & $\mathbf{1 5 2}$ \\
& Total Jumlah (Ekor) & & & & & $\mathbf{4 4 8}$ \\
\hline
\end{tabular}

Tabel 2. Hubungan Jumlah Rajungan dengan Fase Bulan

\begin{tabular}{cccc}
\hline Hubungan & Sig. (2-tailed) & SE & Keterangan \\
\hline Jumlah Total - Fase Bulan & 0,016 & 10,8166 & Ada Hubungan \\
Jumlah Jantan - Fase Bulan & 0,052 & 6,9327 & Ada Hubungan \\
Jumlah Betina - Fase Bulan & 0,005 & 4,4791 & Ada Hubungan \\
\hline
\end{tabular}

Keterangan : Sig. (2-tailed) = signifikansi; $\mathrm{SE}=$ Standart Error

Tabel 3. Jumlah Sebaran Morfometri Rajungan Berdasarkan Lebar Karapas pada Fase Bulan Purnama dan Bulan Baru di Perairan Betahwalang

\begin{tabular}{|c|c|c|c|c|c|c|c|}
\hline $\begin{array}{l}\text { Fase } \\
\text { Bulan }\end{array}$ & $\begin{array}{l}\text { Lebar Karapas } \\
(\mathrm{cm})\end{array}$ & $\begin{array}{l}\text { Jenis } \\
\text { Kelamin }\end{array}$ & 1 (Nov) & 2 (Des) & 3 (Jan) & 4 (Feb) & Total \\
\hline \multirow{6}{*}{ Purnama } & \multirow{3}{*}{ Kecil $\leq 10$} & Jantan & 24 & 17 & 9 & 18 & 68 \\
\hline & & Betina & 15 & 12 & 3 & 8 & 38 \\
\hline & & Jumlah & 39 & 29 & 12 & 26 & 106 \\
\hline & \multirow{3}{*}{ Besar $>10$} & Jantan & 25 & 15 & 11 & 25 & 76 \\
\hline & & Betina & 32 & 26 & 26 & 30 & 114 \\
\hline & & Jumlah & 57 & 41 & 37 & 55 & 190 \\
\hline \multirow{6}{*}{ Baru } & \multirow{3}{*}{ Kecil $\leq 10$} & Jantan & 11 & 9 & 6 & 6 & 32 \\
\hline & & Betina & 8 & 5 & 8 & 9 & 30 \\
\hline & & Jumlah & 19 & 14 & 12 & 15 & 62 \\
\hline & \multirow[t]{3}{*}{ Besar $>10$} & Jantan & 15 & 5 & 15 & 10 & 45 \\
\hline & & Betina & 10 & 7 & 16 & 12 & 45 \\
\hline & & Jumlah & 25 & 12 & 31 & 22 & 90 \\
\hline \multicolumn{3}{|c|}{ Total Jumlah (Ekor) } & & & & & 448 \\
\hline
\end{tabular}


Jumlah Rajungan dengan lebar karapas $>0 \mathrm{~cm}$ pada Bulan Purnama dan Baru lebih banyak dibanding kecil dengan lebar karapas $\leq 10 \mathrm{~cm}$ (tabel 3). Hal ini diduga rajungan dengan ukuran besar hidup pada perairan yang dalam. Menurut Juwana \& Romimohtarto (2005), Fase zoea hingga juvenil hidup di dasar estuari, sedangkan dewasanya dan berkembang biak rajungan menyukai daerah yang dalam dengan salinitas yang tinggi. Rajungan berukuran besar yang tertangkap diduga aktivitas makan bertambah akibat pengaruh fase bulan. Menurut Josilen (2011), rajungan dengan ukuran $101 \mathrm{~mm}-120 \mathrm{~mm}$ paling banyak melakukan aktivitas makan. Rajungan betina diduga mendominasi pada perairan yang dalam dan bersalinitas tinggi 31-34 \%o (tabel 8). Sejalan dengan Adam et al. (2006), Rajungan betina menyukai perairan dengan salinitas tinggi dan perairan dalam. Rajungan besar ditemukan pada suhu yang rendah $27-29{ }^{\circ} \mathrm{C}$ (tabel 8). Menurut Wiyono (2007), rata-rata suhu pada fase bulan Purnama relatif rendah.

Rata-rata berat rajungan jantan pada bulan Purnama 72,89 $\pm 27 \mathrm{~g}$ lebih rendah dibanding bulan Baru 80,58 $\pm 45 \mathrm{~g}$ (tabel 4). Hal ini diduga rajungan jantan pada bulan Purnama cenderung melakukan moulting. Pola pertumbuhan jantan pada bulan Purnama allometrik negatif dan positif,sedangkan pada bulan Baru cenderung positif (tabel 7). Rajungan jantan pada bulan Baru cenderung lebih besar karena sedikit melakukan aktivitas. Rata-rata berat rajungan betina pada bulan Purnama 99,56 $\pm 54 \mathrm{~g}$ lebih tinggi daripada bulan Baru 81,85 $\pm 51 \mathrm{~g}$. Hal ini diduga aktivitas makan rajungan lebih banyak pada fase bulan Purnama sehingga berat rata-rata rajungan lebih tinggi. Menurut Wiyono \& Ikhsan (2015), menyatakan intensitas cahaya mendorong rajungan beraktivitas dan mencari makan, ketika cahaya yang masuk relatif banyak maka aktivitas semakin tinggi sehingga rajungan akan mudah tertangkap.

Rata-rata berat rajungan kecil pada bulan Purnama 51,35 $\pm 11 \mathrm{~g}$ lebih kecil dibanding dengan berat pada bulan Baru 52,29 $\pm 45 \mathrm{~g}$ (tabel 5). Hal ini diduga karena rajungan berukuran kecil cenderung melakukan moulting saat Bulan Purnama. Fase ini fokus pada pertumbuhan lebar

Tabel 4. Kisaran Berat (g) Rajungan Jantan dan Betina pada Fase Bulan Purnama dan Bulan Baru di Perairan Betahwalang

\begin{tabular}{lllrr}
\hline Fase Bulan & Jenis Kelamin & Berat $(\mathrm{g})$ & Rata-Rata Berat $(\mathrm{g})$ & Total (ekor) \\
\hline \multirow{2}{*}{ Purnama } & Jantan & $23-183$ & $72,89 \pm 27$ & 144 \\
& Betina & $25-261$ & $99,56 \pm 54$ & 152 \\
\cline { 2 - 5 } & Jumlah & & $\mathbf{2 9 6}$ \\
\hline \multirow{4}{*}{ Baru } & Jantan & $25-230$ & $80,58 \pm 45$ & 77 \\
& Betina & $25-350$ & $81,85 \pm 51$ & 75 \\
\cline { 2 - 4 } & Jumlah & & & $\mathbf{1 5 2}$ \\
\hline \multicolumn{2}{l}{ Jumlah Total } & & & $\mathbf{4 4 8}$ \\
\hline
\end{tabular}

Tabel 5. Kisaran Berat $(\mathrm{g})$ Rajungan Kecil $(\leq 10 \mathrm{~cm})$ dan Besar $(>10 \mathrm{~cm})$ pada Fase Bulan Purnama dan Bulan Baru di Perairan Betahwalang

\begin{tabular}{llcrr}
\hline Fase Bulan & Ukuran $(\mathrm{cm})$ & Berat $(\mathrm{g})$ & Rata-Rata Berat $(\mathrm{g})$ & Total (ekor) \\
\hline \multirow{3}{*}{ Purnama } & Kecil $\leq 10$ & $23-79$ & $51,35 \pm 11$ & 106 \\
& Besar $>10$ & $58-261$ & $106,2 \pm 12$ & 190 \\
\cline { 2 - 5 } & Jumlah & & & $\mathbf{2 9 6}$ \\
\hline \multirow{3}{*}{ Baru } & Kecil $\leq 10$ & $25-77$ & $52,29 \pm 45$ & 62 \\
& Besar $>10$ & $66-350$ & $101,1 \pm 12$ & 90 \\
\cline { 2 - 5 } & Jumlah & & & $\mathbf{1 5 2}$ \\
\hline \multicolumn{2}{l}{ Jumlah Total } & & & $\mathbf{4 4 8}$ \\
\hline
\end{tabular}


dan sangat rawan terhadap pemangsaan. Menurut Effendy et al. (2006), menyatakan kanibalisme pada rajungan merupakan hal yang umum terjadi baik dewasa maupun juvenil. Rata-rata berat rajunga betina pada bulan Purnama 106,2 $\pm 12 \mathrm{~g}$ lebih tinggi daripada bulan Baru 101,1 $\pm 12 \mathrm{~g}$. Hal ini diduga aktivitas makan rajungan betina pada bulan Purnama bertambah.

Lebar karapas rajungan $>10 \mathrm{~cm}$ lebih didominasi oleh betina pada fase Bulan Purnama maupun Bulan Baru (tabel 6). Hal ini diduga daerah penangkapan pada perairan dalam. Rajungan ditangkap pada kedalam perairan > 20 m dengan salinitas kisaran $30-34 \%$ (tabel 8). Sejalan dengan Adam et al. (2006) menyatakan rajungan betina menyukai perairan dengan salinitas tinggi dan perairan dalam terutama untuk melakukan pemijahan. Rajungan kecil $(\leq 10 \mathrm{~cm})$ yang ditangkap pada Bulan Purnama dan Baru yaitu 168 ekor. Hal ini diduga dapat mengakibatkan populasi rajungan menurun. Sesuai Peraturan Menteri Kelautan dan Perikanan No 01/PERMENKP/2015 tanggal 6 Januari 2015, bahwa penangkapan rajungan (Portunus pelagicus) dapat dilakukan dengan ukuran lebar karapas diatas $10 \mathrm{~cm}$. Kelangsungan hidup rajungan kecil yang tertangkap tidak akan sampai fase dewasa untuk berkembang biak.

Tabel 6. Kisaran Lebar Rajungan Jantan dan Betina pada Fase Bulan Purnama dan Fase Bulan Baru

\begin{tabular}{ccccc}
\hline Fase Bulan & Jenis Kelamin & Lebar $(\mathrm{cm})$ & Rata-Rata Lebar $(\mathrm{cm})$ & Total (ekor) \\
\hline \multirow{3}{*}{ Purnama } & Jantan & $7,0-13,6$ & $10,04 \pm 1,1$ & 144 \\
& Betina & $7,6-15,2$ & $11,19 \pm 1,7$ & 152 \\
\cline { 2 - 5 } & Jumlah & & $\mathbf{2 9 6}$ \\
\hline \multirow{3}{*}{ Baru } & Jantan & $7,7-14,3$ & $10,27 \pm 1,3$ & 77 \\
& Betina & $7,9-16,3$ & $10,48 \pm 1,4$ & 75 \\
\cline { 2 - 5 } & Jumlah & & $\mathbf{1 5 2}$ \\
\hline \multicolumn{2}{c}{ Jumlah Total } & & $\mathbf{4 4 8}$ \\
\hline
\end{tabular}

Tabel 7. Hasil Analisis Regresi Lebar dan Berat Rajungan

\begin{tabular}{|c|c|c|c|c|c|c|}
\hline \multirow{2}{*}{ Fase Bulan } & \multirow{2}{*}{ Jenis Kelamin } & \multicolumn{5}{|c|}{ Hubungan lebar karapas dengan berat } \\
\hline & & $\mathrm{N}$ & $B$ & SE & $\mathrm{R}$ & Pola Pertumbuhan \\
\hline \multirow[t]{2}{*}{ Purnama 1} & Betina & 47 & 3,108 & 0,170 & 0,931 & Isometrik \\
\hline & Jantan & 49 & 2,792 & 0,197 & 0,900 & allometrik negatif \\
\hline \multirow[t]{2}{*}{ Baru 1} & Betina & 18 & 2,894 & 0,392 & 0,879 & allometrik negatif \\
\hline & Jantan & 26 & 3,406 & 0,184 & 0,967 & allometrik positif \\
\hline \multirow[t]{2}{*}{ Purnama 2} & Betina & 38 & 3,329 & 0,116 & 0,979 & allometrik positif \\
\hline & Jantan & 32 & 3,130 & 0,140 & 0,971 & Isometrik \\
\hline \multirow[t]{2}{*}{ Baru 2} & Betina & 12 & 2,934 & 0,351 & 0,935 & allometrik negatif \\
\hline & Jantan & 14 & 2,206 & 0,388 & 0,854 & allometrik negatif \\
\hline \multirow[t]{2}{*}{ Purnama 3} & Betina & 29 & 0,302 & 0,019 & 0,961 & allometrik negatif \\
\hline & Jantan & 20 & 3,273 & 0,248 & 0,952 & allometrik positif \\
\hline \multirow[t]{2}{*}{ Baru 3} & Betina & 24 & 3,401 & 0,189 & 0,966 & allometrik positif \\
\hline & Jantan & 21 & 3,818 & 0.366 & 0,923 & allometrik positif \\
\hline \multirow[t]{2}{*}{ Purnama 4} & Betina & 38 & 3,053 & 0,145 & 0,962 & Isometrik \\
\hline & Jantan & 43 & 3,246 & 0,214 & 0,922 & allometrik positif \\
\hline \multirow[t]{2}{*}{ Baru 4} & Betina & 21 & 3,157 & 0,278 & 0,937 & Isometrik \\
\hline & Jantan & 16 & 3,346 & 0,185 & 0,979 & allometrik positif \\
\hline
\end{tabular}

Keterangan: $\mathrm{N}$ = jumlah sampel; $\mathrm{B}=$ koefisien regresi; $\mathrm{SE}=$ standart error; $\mathrm{R}=$ korelasi 
Journal of Marine Research Vol.8, No.2 Mei 2019, pp. 204-210

Tabel 8. Parameter Lingkungan Perairan Betahwalang

\begin{tabular}{lcccc}
\hline \multirow{2}{*}{ Fase Bulan } & \multicolumn{4}{c}{ Parameter Lingkungan } \\
\cline { 2 - 5 } & Suhu $\left({ }^{\circ} \mathrm{C}\right)$ & Salinitas $(\% \circ)$ & $\mathrm{pH}$ & Kedalaman $(\mathrm{m})$ \\
\hline Purnama 1 & $28-29$ & $32-33$ & $8-8,3$ & $20-21$ \\
Purnama 2 & $28-29$ & $32-33$ & $8-8,2$ & $20-21$ \\
Purnama 3 & $28-29$ & $31-32$ & $8-8,1$ & $24-27$ \\
Purnama 4 & $27-28$ & $30-31$ & $8-8,1$ & $24-27$ \\
\hline Baru 1 & $29-31$ & $32-33$ & $8-8,1$ & $20-21$ \\
Baru 2 & $30-31$ & $33-34$ & $8-8,1$ & $26-28$ \\
Baru 3 & $30-31$ & $32-33$ & $8-8,1$ & $24-26$ \\
Baru 4 & $30-31$ & $33-34$ & $8-8,1$ & $28-30$ \\
\hline
\end{tabular}

Pola pertumbuhan isometrik yaitu pertumbuhan lebar dan berat optimal. Hal ini diduga berhubungan dengan lingkungan, ketersediaan makanan dan kebutuhan tumbuh rajungan. Lingkungan yang mendukung juga berpengaruh terhadap organisme yang hidup perairan tersebut. Ketersediaan makanan mempengaruhi aktivitas migrasi rajungan, semakin banyak makan tapi aktivitasnya sedikit maka pola pertumbuhan bersifat allometrik positif. Pertumbuhan berat pada pola ini lebih cepat daripada pertumbuhan lebarnya. Rajungan yang sedang memijah biasanya mengikuti pola pertumbuhan ini karena sedikit melakukan aktivitas. Rajungan yang sedang moulting diduga cenderung pada pola pertumbuhan allometrik negatif karena lebih fokus pada pertumbuhan lebarnya. Faktor suhu dan salinitas berpengaruh pada pola pertumbuhan, selain itu faktor internal seperti keturunan, seks, umur, parasit dan penyakit.

Suhu pada bulan Purnama relatif lebih randah $27-29^{\circ} \mathrm{C}$ dari bulan Baru $29-31^{\circ} \mathrm{C}$ (Tabel 8). Hal ini diduga pada saat bulan Purnama terjadi pasang tertinggi yang menyebabkan teraduknya kolom perairan sehingga panas yang diterima akan berkurang. Posisi bulan dan matahari sejajar terhadap bumi maka gaya keduanya akan bergabung dan mengakibatkan pasang dengan kisaran terbesar baik naik maupun turun (pasang purnama/spring tides). Rajungan bertahan hidup pada kisaran suhu tersebut dah hewan ini diduga menyukai perairan dengan salinitas tinggi, sehingga pada bulan Purnama hasil tangkapannya lebih tinggi. Salinitas yang didapat yaitu kisaran 30 - 34 \% pada fase bulan Purnama lebih rendah daripada bulan Baru. Hewan ini diduga menyukai salinitas yang tinggi terutama betina, sehingga rajungan yang tertangkap didominasi betina. Menurut Kembaren et al (2012), Rajungan hidup pada suhu kisaran $20-35{ }^{\circ} \mathrm{C}$ dan salinitas diatas $30 \%$. $\mathrm{pH}$ yang didapat kisaran $8-8,3$ yang menunjukkan cenderung basa. Hal ini diduga pengambilan sampel air dilakukan pada siang hari. pH naik disebabkan kelarutan $\mathrm{CO}_{2}$ yang rendah dengan temperatur laut relatif lebih tinggi. Proses fotosintesis semakin tinggi maka semakin rendah kadar $\mathrm{CO}_{2}$ diperairan (Safitri \& Putri, 2009). Betina pada fase Bulan Purnama lebih banyak dibanding jantan, hal ini diduga lokasi penangkapan pada perairan dalam 20 - $27 \mathrm{~m}$. Rajungan jantan menyukai perairan dengan salinitas yang rendah sehingga penyebarannya disekitar perairan dangkal. Betina menyukai perairan dengan salinitas tinggi terutama untuk melakukan pemijahan, sehinga penyebarannya pada perairan yang lebih dalam (Adam et al., 2006).

\section{KESIMPULAN}

Jumlah rajungan yang tertangkap yaitu 448 ekor, pada fase bulan Purnama 296 ekor lebih banyak dibanding fase bulan Baru 152 ekor. Morfometri rajungan yang tertangkap ukuran $>10 \mathrm{~cm}$ pada bulan Purnama 190 ekor lebih banyak dari bulan Baru 90 ekor. Ukuran $\leq 10 \mathrm{~cm}$ pada bulan Purnama 106 ekor lebih banyak dari bulan Baru 62 ekor.

\section{DAFTAR PUSTAKA}

Adam, J.I. \& Sondita, M.F. 2006. Model Numerik Difusi Populasi Rajungan di Perairan Selat Makassar. Jurnal IImu-ilmu Perairan dan Perikanan Indonesia, 13(2):83-88. 
Effendie, M.I. 2002. Biologi Perikanan. Yogyakarta: Yayasan Pustaka Nusantara

Effendy, S., Sudirman, Bahri, S., Nurcahyono, E., Batubara, H. \& Syaichudin, M. 2006. Petunjuk Teknis Pembenihan Rajungan (Portunus Pelagicus Linnaenus). Diterbitkan Atas Kerjasama Departemen Kealutan dan Perikanan, Direktorat Jenderal Perikanan dengan Balai Budidaya Air Payau, Takalar.

Hastuti, S., Arifin, S., \& Hidayati, D. 2012. Pemanfaatan Limbah Cangkang Rajungan (Portunus pelagicus) sebagai Perisa Makanan Alami. Agrointek, 6(2):88-96

Josileen, J. 2011. Food and Feeding of the Blue Swimmer Crab, Portunus pelagicus (Linnaeus, 1758)(Decapoda, Brachyura) Along the Coast of Mandapam Tamil Nadu India. Crustaceana. 84(10):1169-1180.

Juwana, S \& Romimohtarto. 2005. Biologi Laut Ilmu Pengetahuan Tentang Biota Laut. Djambatan, Jakarta

Kembaren, D.D., Ernawati, T. \& Suprapto. 2012. Biologi dan Parameter Populasi Rajungan (Portunus pelagicus) di Perairan Bone dan sekitarnya. Jurnal Penelitian Perikanan Indonesia. Diterbitkan oleh Pusat Penelitian Pengelolaan Perikanan dan Konservasi Sumber Daya IkanBadan Penelitian dan Pengembangan Kelautan dan Perikanan Kementerian Kelautan dan Perikanan Republik Indonesia.

Kementerian Kelautan dan Perikanan. 2015. Peraturan Menteri Kelautan dan Perikanan Nomor 1 Tahun 2015 tentang Penangkapan Lobster (Panulirus spp.), Kepiting (Scylla spp.), dan Rajungan (Portunus pelagicus spp.). Jakarta (ID): Kementerian Kelautan dan Perikanan. $5 \mathrm{hlm}$

Ningrum, V.P. 2015. Beberapa Aspek Biologi Perikanan Rajungan (Portunus pelagicus) di Perairan Betahwalang dan Sekitarnya. Program Studi Manajemen Sumberdaya Perikanan, Universitas Diponegoro, $84 \mathrm{hlm}$

Safitri, M. \& Putri, M.R. 2009. Kondisi Keasaman (pH) Laut Indonesia. Kelompok Keahlian Oseanografi. Fakultas IImu dan Teknologi Kebumian. Institut Teknologi Bandung. Bandung.

Sukmadinata. 2006. Metode penelitian kualitatif. Bandung. Graha Aksara

Susilo. 1993. Pengaruh Hari Bulan (Moon's cycle) terhadap Hasil Tangkapan Pukat Rajungan di Perairan Tanggung Tikar, Kecamatan Tanjung Pandan Belitung.Program Studi Pemanfaatan Sumber Daya Perikanana. Fakultas Perikanan dan Ilmu Kelautan. Institut Pertanian Bogor.

Wiyono E.S. 2007. Hasil Tangkapan Dinamis Harian Biru Terbang Kepiting (Portunus pelagicus) dengan Hubungan dalam Siklus Bulan di Bondet Waters, Cirebon. Buletin PSP 16(1):138-145

Wiyono E.S. \& Ihsan. 2015. The Dynamic of Landing Blue Swimming Crab (Portunus pelagicus) Catches in Pangkajene Kepulauan, South Sulawesi, Indonesia. Aquaculture, Aquarium, Conservation \& Legislation. International Jurnal of the Bioflux Society, 8(2):134-141 